\title{
18th Century Wooden Churches of Povazhye: Traditions and Local Peculiarities
}

\author{
Olga Zinina ${ }^{1, *}$ \\ ${ }^{1}$ Scientific Research Institute of the Theory and History of Architecture and Urban Planning, Branch of the \\ Federal State Budget Institution "Central Scientific-Research and Project Institute of the Construction Ministry \\ of Russian Federation”, Moscow, Russia \\ ${ }^{*}$ Corresponding author. Email: olg-zinina@yandex.ru
}

\begin{abstract}
The article deals with insufficiently explored wooden church monuments of the 18th century in the Shenkursky uyezd of the Arkhangelsk province. Methodology is based on studying archival historical sources, conducting field surveys and historical-architectural analysis of shapes, as well as comparison with analogues. The study aims to identify the peculiarities of architectural and structural solutions of the objects by comparing them with their analogues in the broad context of wooden architecture of the entire region. Architectural peculiarities of the churches in question revealed by the study correspond to the characteristic traditions of wooden architecture in Povazhye. Typological analysis of the studied objects is provided.
\end{abstract}

Keywords: Monuments of wooden architecture, Wooden churches, Povazhye region, Traditions, Shenkursky uyezd.

\section{INTRODUCTION}

Wooden architecture of the Russian North represents a complex intertwined knot of traditions. They are related to historical situation, trade and economic connections, geographical, local ethnic and other factors. The article considers a separate region featuring a great typological diversity of church buildings.

The territory of interest includes the lands along the Vaga River - one of the largest rivers in the Russian North. Historically, this area was a part of the Shenkursky uyezd (county) of the Arkhangelsk province. This area came to be known as Povazhye (literally — "lands along Vaga"). In the olden days, a lot of wooden churches and chapels were located there. According to the documents dated 1895, this region accommodated 88 wooden churches and 72 chapels [1]. Only a few of them have survived until the present time. Churches of the $17^{\text {th }}$ century were completely lost in the middle of the $20^{\text {th }}$ century. As

*Fund: This study is based on the research, supported by the Program of Fundamental Research of the Russian Academy of Architecture and Construction Sciences and of the Ministry of Construction, Housing and Utilities of the Russian Federation 2021. of now, seven churches and three chapels of the $18^{\text {th }}$ century still remain there. About 20 objects date back to the $19^{\text {th }}$ - early $20^{\text {th }}$ century.

We are going to consider the objects of the $18^{\text {th }}$ century. They constitute a considerable and an almost unexplored group of wooden architecture monuments of that period. Most of them have been lost. However, despite numerous losses, we still have archival materials with photographs and descriptions of the objects. This helps to re-create the appearance of some churches and get a broader overview of the $18^{\text {th }}$ century wooden church architecture.

Architectural traditions, their development and impact on wooden architecture of the region have not been fully covered by previous studies. Local peculiarities and specific features of wooden architecture in Povazhye have not been revealed, despite the fact that there were some studies dedicated to this area. At the end of the $19^{\text {th }}$ century, during his expedition trips to the Vaga River lands, V.V. Suslov noticed some octagon-onquadrangle churches with onion-shape tops. These churches were later mentioned in the works of A.B. Bode [2]. 
D.V. Mileev did an extensive research on wooden churches of the Shenkursky uyezd. He took measurements and pictures of numerous churches, and was the first to introduce some of them into the scientific discourse [3].

At the beginning of the $20^{\text {th }}$ century, I. Ya. Bilibin visited the Arkhangelsk province under the assignment of the ethnographic department of the Alexander III Museum to study wooden architecture. In the Shenkursky uyezd, he placed both individual structures and entire church ensembles on record.

Let us review various church buildings with different types of top elements and layout.

\section{CHURCHES WITH TENTED ROOFS}

In the $18^{\text {th }}$ century, the prevailing type of top structure for wooden churches in the Russian North was tented roof. Let us have a look at this type of churches in the area of interest.

The only example of a tented-roof church with the top structure still intact is the Saint Elijah Church (1798) in the village of Seltso. The main volume of the church consists of an octagon based on a quadrangle, with an annexed five-sided altar and a two-pillar refectory.

There is another church of this type, but its tent top has been lost. This is the Church of the Nativity (1769) in the village of Bolkachevskaya, Ustpuysky parish ("Figure 1"). The original church has an octagon-on-quadrangle design, which was a traditional arrangement for a wooden church widely spread over the Russian North in the $18^{\text {th }}$ century. [4]. It was built on a high ground floor, with a high single-stair porch. The main volume was occupied by the first floor of the church including a narthex, a refectory, a prayer room, and an altar. The upper church occupied the main quadrangle, to which a small narthex was annexed above the refectory. In terms of the top structure, this is a tented-roof church. According to the archival documents, the tent was covered with wooden shingles (lemekh).

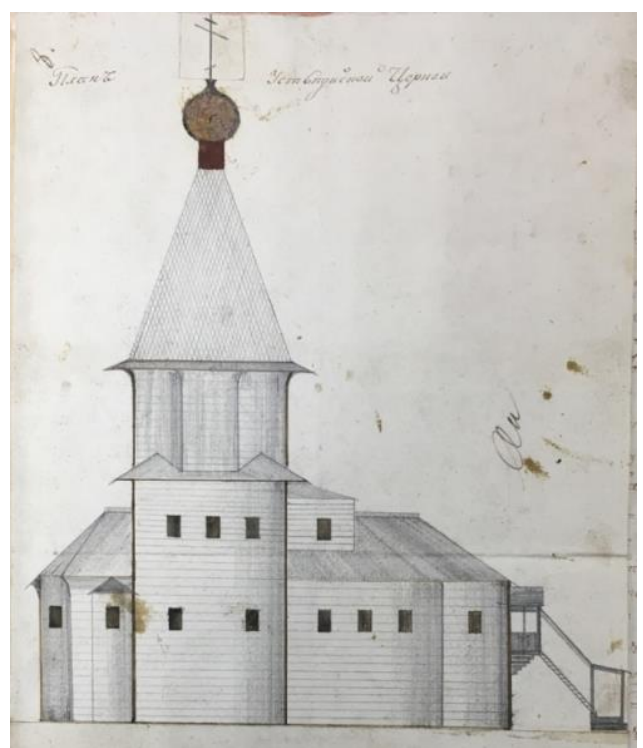

Figure 1 The northern facade of the Nativity

Church in the Bolkachevskaya village, $1796^{1}$.

Not far from the Bolkachevskaya village, there was an earlier tented-roof church - the Church of the Dormition (1667) in the Sulanda settlement. A distinctive feature of this building was four attachments, one on each side oriented in cardinal directions, with the so-called bochka ("barrel") roofs. This was a traditional design for a wooden church of the early $17^{\text {th }}-$ the first half of the $18^{\text {th }}$ century. There are two other churches of the same type (octagon-on-quadrangle with four side attachments) in the Shenkursky uyezd: The Church of the Nativity of the Theotokos (1726) in the Zaostrovye settlement (Yakovlevskaya church) and the Church of Ascension (1752) in Konetsgorye.

Another tented-roof church is the Saints Peter and Paul Church (1729) in the village of UstSyuma ("Figure 2") and its closest but older analogue - the Trinity Church (1666) in the village of Shegovary. The main distinctive feature of these monuments is that the main quadrangle is dominating. The west and east side attachments of narthex and altar are smaller in volume. They both have bochka ("barrel") roofs. Both churches were not only located close to each other, but also very similar in appearance. They have the same proportions. There is an enclosed log gallery annexed to both churches on the west side. Most likely, the gallery is a later addition, because the narthex has its own windows. A unique feature of these churches is corbel arches (kokoshnik) on pedestals at the transition from the quadrangle to

1. GAAO, F9. Op.4. Vol.2. C. 1651. L. 8 (State Archive of the Arkhangelsk Region) 
the octagon. Corbel arches without pedestals can be found in the regions of the Dvina and Onega Rivers, and in Pomorye. However, this combination can only be observed at four objects: the two above, as well as two churches in Nyonoksa (the Saint Nicholas Church, 1763, and the Trinity Church, 1727). Similar to the Bolkachevskaya village church, the tented roofs on the churches in the UstSyuma and Shegovary villages are covered with wooden shingles.

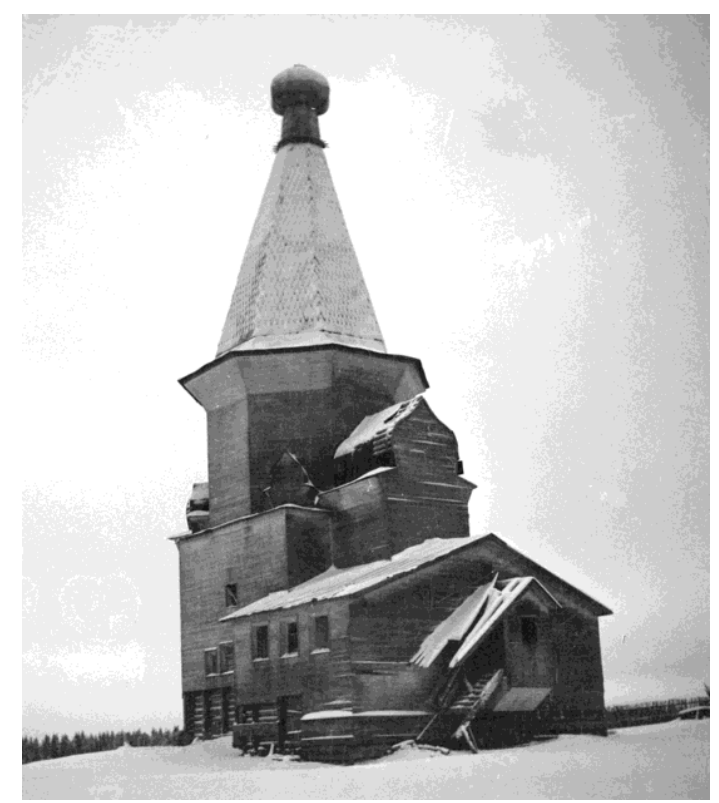

Figure 2 The Saints Peter and Paul Church in the Ust-Syuma village, $1729^{2}$.

Another example of a tented-roof octagon-onquadrangle church with two side attachments is the Trinity Church (1707) in the Rostovskoye settlement. The comparison with the analogues clearly identifies the difference between the buildings of the beginning and the second half of the $18^{\text {th }}$ century. Examples of such a combination include the Church of Saint Michael the Archangel in the Zaostrovye settlement (Yakovlevskaya Church), the Church of the Holy Sign (1762) in the Verkhnyaya Kitsa settlement, the Saint Nicholas Church (1774) in the Kalyi settlement, and the Saint Elijah Church (1798) in the Seltso settlement. A distinctive feature of these churches is the refectory expanding in plan in relation to the main volume.

2. General funds, Scientific Archive, IHMS RAS. I91888 (Ust-Syuma, Shenkursky district, the Arkhangelsk region. Wooden church - outer appearances. Archeological expedition of the State Russian Museum, 1964. E.S. Smirnova)

\section{CHURCHES WITH ONION- SHAPED ROOFS}

By the middle of the $18^{\text {th }}$ century, tented roofs were replaced with octagonal onion-shaped domes (puchina). This type of roof became very popular in Povazhye and in the middle reaches of the Northern Dvina River. The main volume of the church remained the same: a typical octagon-onquadrangle design. The only thing that changed was the proportions.

Among this type of buildings are the Saint John Chrysostom Church (1733) in the Bereznitskoye settlement (Bereznitsky parish), the Saint Nicholas Church (1799) in Verkhne-Padengsky Nikolsky parish, the Church of the Holy Sign (1762) in the Kitskoye settlement (Kitsky parish) [5]. These churches have not survived until the present day. The only remaining church of this type in the Shenkursky uyezd is the Church of Saint John the Baptist (1780-1781) in the village of Litvinovo. The main volume of these buildings was represented by an octagon on a quadrangle with an octagonal onion-shaped dome.

Apart from the listed structures, we know of other churches of the octagon-on-quadrangle type with an onion-shaped roof located in the neighbourhood: the Saint Elijah Church (1756) in the Vozgretsovskaya (Rostovskoye) village [6], the Church of the Nativity of the Theotokos (1767) in the Nikiforovo village, the Saint Nicholas Church (1790-1792) in the Gridinskaya village [7], the Church of Ascension (1791) in the Kozlovskoye settlement, and the Church of the Dormition (17931803) in the town of Velsk. All these structures are united by a massive octagonal onion-shaped puchina on a low octagon, which dominates over the entire volume of the church. This cannot be said, for example, about the Saint Blaise Church (1795) in the Tulgas settlement, where the octagon is smaller in width relative to the base quadrangle. This gives certain lightness to the general arrangement of the church, emphasizing its height.

The shape of the octagonal onion-shaped puchina deserves special attention. For example, the dome's external contour of the Litvinovo village church differs significantly from supposedly similar shapes on the churches in the Zachachye and Gridinskaya villages ("Figure 3"). Roof centering elements feature reverse curvature at their base, and their upper part is quite low-pitched at the transition from the largest radius to the base of the neck. It gives the general impression of a vertically 
compressed top, as different from similar churches in the southern reaches of the Vaga River with characteristic radial lines and interfaces. This
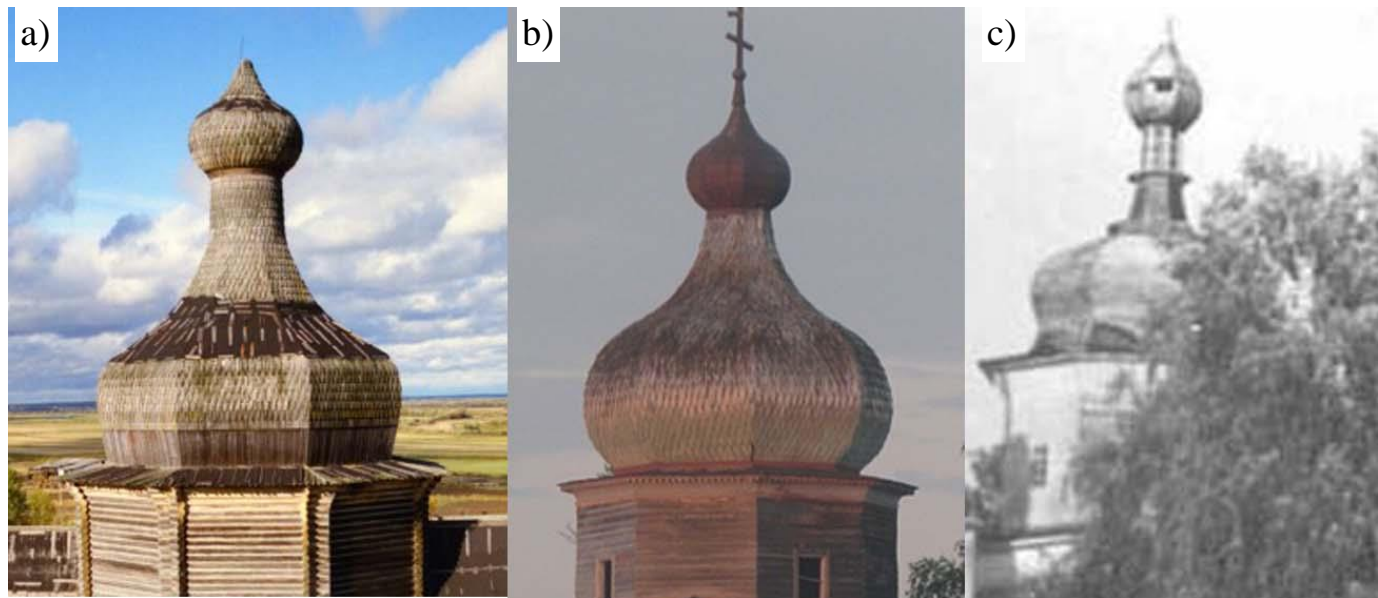

Figure 3 a) The Saint Nicholas Church in the Zachachye village, 1687 (1909-1914); b) The Saint Nicholas Church in the Gridinskaya village, 1790-1792; c) The Church of Saint John the Baptist in the Litvinovo village, 1780-1781.

Povazhye churches are characterised by the same general type of the top having different structural designs, which leads to a different visual perception of the familiar shape. Another example is an unknown church on the Vaga River bank, between the villages of Ofyorovo and Kremlikha (Molodikhinskoye) ("Figure $4{ }^{\prime \prime}$ ). Here we have the roof in the form of a "flattened" octagonal onion with a conical top.

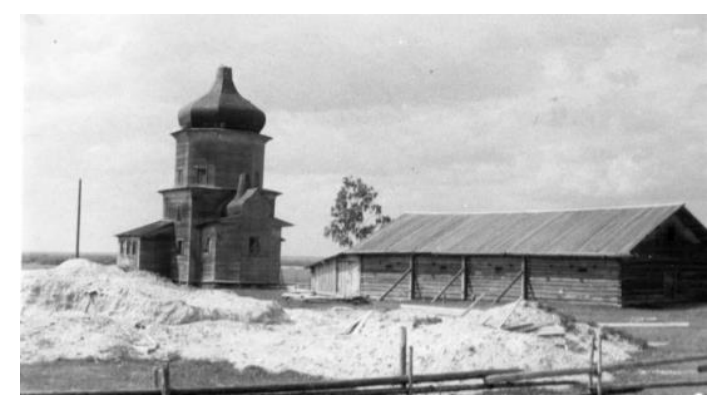

Figure 4 An unknown church on the Vaga River bank, between the villages of Ofyorovo and Kremlikha (Molodikhinskoye), $18^{\text {th }}$ century.

\section{CHURCHES WITH TIERED ONION-SHAPED ROOFS}

The 18th century witnessed unique transitional forms of church tops, for example, on the Church of the Three Hierarchs (1782) in the parish of John the Apostle. The top of the main volume is represented by a three-tier onion dome roof. As of today, no makes the octagonal top somewhat lower due to its structural design. equivalents of this church in terms of the top structure shape have been found in the Russian wooden architecture. We can only talk about the onion-type octagonal roof shape (or puchina, in other terms) atop the octagons of wooden churches.

The Church of the Three Hierarchs, same as the majority of onion dome churches, is characterised by general upward orientation of the central volume ("Figure 5"). Despite the large number of similar monuments, none of them features a prominent tiered design. This is what makes this object unique.

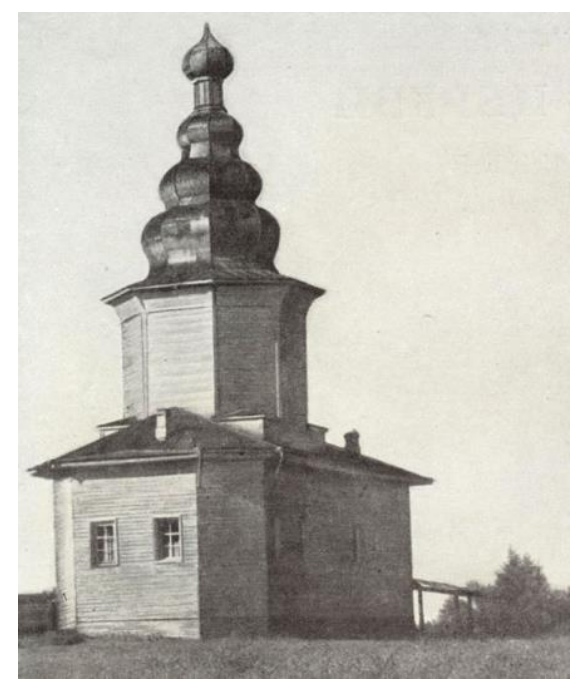

3. MBUK Shenkurskiy regional museum of local lore. Scientific auxiliary fund, No. 1849, 1960s. 
Figure 5 The Church of the Three Hierarchs in the parish of John the Apostle, 17824.

In a 1942 publication, the Church of the Three Hierarchs was classified as a tented-roof church. According to the authors, another unique structure - the wooden Church of Saints Anne and Joachim (1726) in the Morzhegory settlement — also belonged to this type. However, neither of them fit the description of a classical tented-roof church. The top structure of the Morzhegory church can hardly be called an octagonal puchina, too. It is a tent "...with a curved profile bent inwards at its base". Both buildings shall be referred to as structures with a transitional roof type.

It has been suggested that the top structure of the Church of the Three Hierarchs appeared "...under the influence of the Ukrainian tiered churches where each tier is covered with a banya (a curved profile roof)...", which "...speaks of extraordinary technical skills of the local woodworkers coming from the Vaga region" [8].

In terms of the tiered top structure, the closest analogues among the Transcarpathia region churches are the Church of the Presentation of the Blessed Virgin Mary (1759) in the Rostoka settlement [9] and the Saint Nicholas Church of $\left(18-19^{\text {th }}\right.$ century) in the Podobovets settlement, Mezhgorsky district [10]. A distinctive feature of these churches is the base in the form of a quadrangle bearing octagonal onion-shaped roofs. The division of the surface into eight sections starts at the first tier of banya, whereas the overhangs (politsa - low-pitched panel protecting the wall against rainwater) underneath are considered a part of the quadrangle and have four slopes. The Church of the Protection of the Holy Virgin (1775) in the Pekariv settlement, Chernigov region, features a three-tiered top, with each tier separated by a small octagon, which makes it different from the Church of the Three Hierarchs [11]. The Saint Paraskevi Church (1811) in the Kwiaton settlement is a structure with three dominant elements. The upper tiers are shaped as octagonal onion-shaped puchinas, and the lower tiers are quadrangles [12].

Therefore, upon reviewing some Transcarpathian churches, we can argue that there are no direct equivalents to the church of the parish of John the Apostle parish there. The materials presented allow us to suggest that the Church of the

4. S. Zabello, V. Ivanov, P. Maximov. Russian wooden architecture. Moscow: State Architectural Publishing House Academy of Architecture of the USSR, 1942, p. 143
Three Hierarchs is a typical representative of the Russian wooden architecture of the $18^{\text {th }}$ century, in which alongside the traditional ways, the influence of the Western church architecture can be observed.

\section{CHURCHES WITH BOCHKA-TYPE ROOFS}

At present, a unique type of top structure above the church main volume is bochka ("barrel"). Based on the archival note of a "curved double-pitched roof" on the Church of the Nativity of the Theotokos (1794) in the Bolkachevskaya village, of the Ustpuysky parish (Shenkursky uyezd), one can suggest that this roof type also existed in Povazhye. The expression "curved roof" might refer to an octagonal onion-shaped (puchina) or a regular dome. In this case, the number of slopes is indicated, i.e. we are talking about a curved gable (double-pitched) roof. Therefore, it is likely that this phrase shall be understood as a reference to the bochka top.

There existed other buildings with similar top structures. For example, the chapel in the village of Nizhniye Markomusy (1725), the Trinity Church in the Elgomsky pogost ("churchyard") (1643-1644), the church in the Pochozersky pogost (early 18th century). Unfortunately, none of these buildings have survived. Today, one can only observe the bochka shape in altar attachment roofs. The only example of a church with a bochka above the main volume is the Church of Annunciation in the Pustynka village (1719-1725) of the Plesetsky district, Arkhangelsk region. The only example of a chapel is the Saint George Chapel (1732) in the Dyvlevskaya (Kotazhka) village of the Shenkursky district, Arkhangelsk region. Compared to the above-mentioned monuments, the Kotazhka chapel has a distinct difference. Despite the fact that bochka is the dominant volume, its size is relatively small compared to the overhangs (politsa). The curvature of the bochka's slope is small, and the ogee top is unpronounced. The widening of the main volume (poval) is barely noticeable.

\section{CHURCHES WITH STEEP GABLE ROOFS}

No steep gable ("wedge") roof churches of the 18th century have been found in Povazhye. We only know of two chapels dating back to the first third of the $18^{\text {th }}$ century: the Saint Nicholas chapel in Charostrovo village ("Figure 6") and the Saint George Chapel in Ermolinskaya village. 


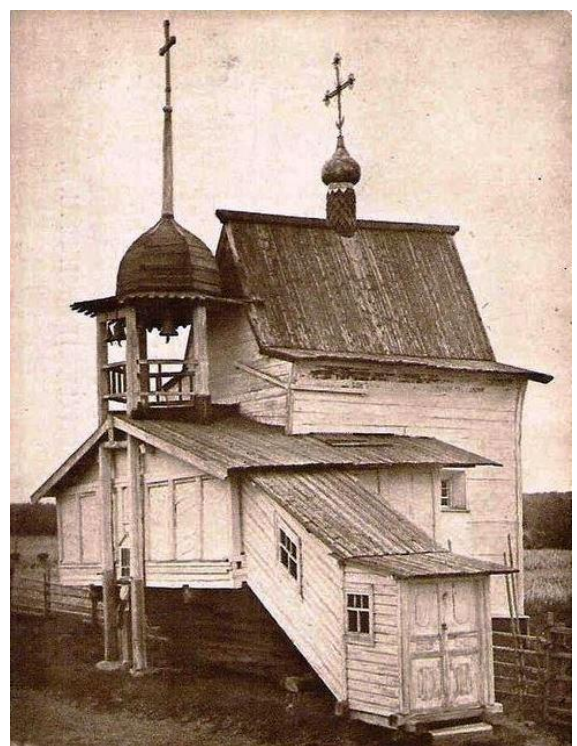

Figure 6 The Saint Nicholas chapel in the Charostrovo village, 18th century5.

In the $17^{\text {th }}$ century, however, there existed some buildings with this top structure design in the area. For example, the Church of the Dormition (1675) in Ust-Padenga represented a klet'-type structure with two attachments on a high ground floor with a steep gable roof. There is another, a one-of-a-kind structure - the Church of the Presentation of the Blessed Virgin Mary (1684) in the village of Osinovo. Its unique character resides in the double wedge roof above the main volume.

\section{CONCLUSION}

Wooden churches of the $18^{\text {th }}$ century in the Russian North constitute the majority of traditional church structures still standing today. Their structural design was so over-conservative that given proper care and maintenance these buildings can remain in excellent condition up to this day, compared to more recent structures of the $19^{\text {th }}$ century.

Being previously unexplored, the wooden churches of Povazhye were a blank space on the map of local church-building traditions of the Russian North. The knowledge of local architectural traditions and their development have been rather superficial until very recently.

The Shenkursky uyezd monuments are interesting for their typological diversity. In the $18^{\text {th }}$ century, in the area in question, there were newer churches constructed, and the older ones preserved.

5. News of the Imperial Archeological Commission, Issue 41. Saint Petersburg, 1991, p. 216
Thus, a wide range of different forms of wooden church top structures co-existed at the time: tent, bochka, puchina, steep gable and square onion dome, double wedge, tiered puchina, and similar transitional forms. No other region of the Russian North can boast such a variety of designs [13].

This is the first comprehensive study of the $18^{\text {th }}$ century wooden church architecture in Povazhye. Previously unexplored objects have been introduced into the scientific discourse. New archival references for the construction history of the churches in question have been mentioned. Field survey results have been used to expose the construction history of the objects and reveal their main construction stages. The objects studied have been compared to each other, and to their analogues in terms of their typological characteristics. This is the first review of architectural tradition development in the studied area and the interconnection of these traditions with the wooden architecture of the entire Russian North.

This new research allows for a fresh look into the poorly explored region as a whole. The results obtained can be used in the field of restoration and protection of wooden architecture monuments [14].

The study of the $18^{\text {th }}$ century wooden architecture monuments in Povazhye continues the author's research of the wooden architecture monuments in this area. Together, these works will constitute a full-fledged research of local architecture.

\section{AUTHORS' CONTRIBUTIONS} Zinina.

This paper is independently completed by Olga

\section{REFERENCES}

[1] A Brief Historical Description of the Parishes and Churches of the Arkhangelskaya Diocese. Issue 2. Uyezds: Shenkurskiy, Pinezhskiy, Mezenskiy and Pechorskiy (Kratkoe istoricheskoe opisanie prihodov i tserkvei Arhangelskoi eparhii. Vypusk II. Uezdy: Shenkurskii, Pinezhskii, Mezenskii i Pechorskii), Arhangelsk, 1895, pp. 5-6 [in Russian].

[2] A. Bode, Onion-Shaped Single-Headed Completions as One of the Characteristic Features of the Wooden Churches of the Povazhye and Severodvinsk River Area (Lukovitseobraznye odnoglavye zaversheniia 
kak odna iz harakternyh osobennostei dereviannyh tserkvei Povazhya i Severodvinskogo Porechya) Architectural Heritage (Arkhitekturnoe Nasledstvo) 61 (2015) 70-84 [in Russian].

[3] E. Khodakovsky, E. Meliukh, Dmitrii Mileev and the Restoration of Wooden Architectural Monuments in Early XXth century Russia, Russian Review 2 (74) (2015) 247-271. DOI: https://doi.org/10.1111/russ.10768

[4] A. Bode, Traditional Structures in Russian Wooden Architecture: Technical Aspects Historic Wooden Architecture in Europe and Russia, in: E. Khodakovsky, S. Skjold Lexau (Eds.), Evidence, study and restoration, Basel, 2015, pp. 110-121.

[5] News of the Imperial Archeological Commission (Izvestiia imperatorskoi arheologicheskoi komissii), vol. 41, SaintPetersburg, 1991, pp. 185-197 [in Russian].

[6] A. Bode, Wooden Churches in the Vicinity of Velsk (Dereviannye tserkvi v okrestnostiah Vel'ska), in: Wooden Architecture. New Materials and Discoveries (Dereviannaia arkhitektura. Materialy i otkrytiia), vol. 3, Saint-Petersburg, Moscow, 2013, p. 241 [in Russian].

[7] Z. Todorova, I. Voyevodin, Saint Nocholas Church of the Gridinskaya village, Veslky district. Restoration Project (Nikol'skaia tserkov' derevni Gridinskoi Vel'skogo raiona. Restavratsionnoe reshenie), in: Z. Todorova, I. Voyevodin (Eds.), Restoration and Exploration of Architectural Monuments, vol. 9, Kolo, Saint Petersburg, 2017, pp. 145 [in Russian].

[8] S. Zabello, V. Ivanov, P. Maximov, Russian wooden architecture (Russkoe dereviannoe zodchestvo), Academy of Architecture of the USSR (Academia arkhitektury SSSR), Moscow, 1942, p. 143 [in Russian].

[9] D. Goberman, Wooden Architectural Monuments of Trans-Carpathia (Pamiatniki dereviannogo zodchestva Zakarpat'ia), Avrora, Leningrad, 1970. p. 17 [in Russian].

[10] P. Makushenko, Folk wooden architecture of Trans-Carpathia (XVIII-early XX centuries), (Narodnaia dereviannaia arkhitektura Zakarpat'ia (XVIII-nachala XX veka),
Stroiizdat, Moscow, 1976, pp. 124-125 [in Russian].

[11] S. Taranushenko, Monumental Ukrainian Wooden Architecture (Monumental'na derev'iana Arkhitektura Livobeerezhnoi Ukrainy), Kiev, Budivel'nik, 1976, pp. 248249 [in Ukrainian].

[12] O. Ivanusiv, Church in Ruins. Religious Association of Ukrainian Catholics in Canada (Tserkov' v ruinah. Religioznoe tovarishchestvo ukraintsev katolikov v Kanade.), Publishing house, Saint Sophia, 1987, p. 72 [in Ukrainian].

[13] E. Khodakovsky, Wooden church architecture of the Russian North: Regional Schools and Traditions, Routledge, London, New York, 2016.

DOI: https://doi.org/10.4324/9781315723181

[14] A. Bode, Methods of the Restoration of Wooden Architectural Monuments in Russia, in: Advances in Social Science, Education and Humanities Research, vol. 324. Proceedings of the 2019 International Conference on Architecture: Heritage, Traditions and Innovations (AHTI 2019), pp. 357-361. DOI: https://dx.doi.org/10.2991/ahti-19.2019.66 